\title{
Antioxidant and anti-inflammatory activity on sea tangle (Laminaria japonica) adding vinegar
}

\author{
You Seong Ahn* \\ Department of Hotel Food Service Culinary Arts, Gwang-ju University, Gwangju 61743, Korea
}

\section{다시마(Laminaria japonica) 첨가에 따라 제조된 식초의 항산화 및 항염증 활성 비교}

\author{
안유성* \\ 광주대학교 호텔외식조리학과
}

\begin{abstract}
The objective of this study was to evaluate the antioxidant and anti-inflammatory activity of vinegar with added sea tangle (Laminaria japonica) (VAST). To determine the antioxidant activity, DPPH and ABTS radical scavenging activity, reducing power, and total polyphenolic and flavonoid contents were evaluated. The anti-inflammatory activity was determined using lipopolysaccharide (LPS) induced macrophage (RAW 264.7). Finally, the antioxidant and anti-inflammatory activities of VAST were compared with those of vinegar without added sea tangle (VNAST). The antioxidant activity, total polyphenol content, and total flavonoid content were all higher in VAST than in VNAST. Moreover, neither VAST nor VNAST displayed toxicity toward RAW 246.7 cells at up to 200-fold dilution. In LPS-induced RAW 264.7 cells, VAST treatment significantly decreased the production of nitric oxide and inflammatory cytokine (TNF-a) compared with VNAST treatment. Overall, VAST showed exhibited superior antioxidant and anti-inflammatory activities compared with VNAST. These results clearly indicate that VAST has the potential for use as an anti-oxidant and anti-inflammatory agent in functional foods.
\end{abstract}

Key words : sea tangle vinegar, radical scavenging, total polyphenol contents, nitric oxide inhibition, inflammatory cytokine inhibition

\section{서 론}

식초는 산미료로서 발효과정 중 산미와 방향을 가지는 대표적인 발효식품이다(1). 초산함량 $4-29 \%$ 의 식용 식품으 로 음식을 조리할 때 신맛을 내는 조미료로 사용되며, 체내 소화 기관을 자극하여 식욕증강과 소화액 분비촉진과 생선 의 비린 냄새를 없애거나 육류의 연질을 조절하는 작용도 한다(2). 식초는 제조방법과 원료에 따라 식초의 유기산, 유리아미노산 등 휘발성 성분들의 함량이 다르며, 이렇게

*Corresponding author. E-mail : ahn7712@naver.com Phone : 82-62-352-7711; Fax : 82-62-352-7713

Received 13 February 2019; Revised 7 March 2019; Accepted 12 March 2019.

Copyright (c) The Korean Society of Food Preservation. All rights reserved.
제조된 식초들은 체지방 감소에 도움을 주고, 전분분해효 소 저해 및 신진대사 활성화 등을 통해 당뇨병과 같은 성인 병 예방 효능이 보고되고 있다(3-5). 또한 식초에는 노화를 비롯한 각종 성인병의 원인이 되는 활성산소를 억제시키는 항산화 효능이 높다는 보고도 있다(6,7).

식초는 제조 방법에 따라 양조식초와 희석초산으로 분류 되며, 양조식초의 경우, 누룩을 이용하여 만든 발효주정을 초산 발효하는 전통방식과, 효모를 이용한 발효주정을 초 산 발효 하는 두 가지 방법으로 제조하는 것을 특징으로 하며, 희석초산은 초산을 물로 희석하여 제조하는 간단한 방법으로 제조하는 것을 특징으로 한다 $(8,9)$. 양조식초는 비교적 초산발효 시간이 길어 제품 생산기간이 길고, 제품 가격이 높으며, 일정기간 품질 유지가 어렵다는 단점 때문 에, 현재 대량생산을 위한 상업적인 목적으로 희석초산이 널리 이용되고 있으나, 최근에는 합성원료 사용에 따른 안 
정성의 문제와 건강에 대한 소비자 인식 변화에 따른 소비 시장의 변화로 인해, 양조식초에 대한 수요 증가로 다양한 천연물과 과일을 이용한 식초의 제조에 관련된 연구가 활발 하게 이루어지고 있다(10-12).

다시마(sea tangle; Laminaria japonica)는 아시아 해안에 서 많이 분포하는 갈조식물군 중 다시마과에 속하며, 우리 나라에는 남해안에 많이 서식하고 있다. 일반적으로 다시 마는 천연 정미성분인 아미노산(glutamic acid 및 aspartic acid 등)과 칼륨, 나트륨, 칼슘, 마그네슘 등 신체의 생리대 사에 관여하는 무기질이 풍부한 식품으로 알려져 있다. 동 의보감에서는 '곤포'라 하여 신체의 저항성을 높여주고, 노폐물의 배설을 촉진하며, 고혈압, 동맥경화, 갑상선종, 신장염에 효과가 있을 뿐만 아니라 암세포 증식을 억제하 고, 노화를 예방하는 건강장수식품으로 기록되어 있다 $(13,14)$. 다시마에 관련된 국내연구로는 다시마 열수추출물 의 성분 및 항산화 효과(14), 다시마 분말이 당뇨유발 쥐의 혈당과 지질농도 및 항산화 효소계에 미치는 영향(15), 유산 균을 이용한 다시마 발효물의 알코올 분해 활성(16) 등이 보고되어 있다. 다시마를 이용한 가공식품에 관한 연구는 추출방법을 달리한 미역 및 다시마 과립차의 품질 및 항산 화 특성(17), 다시마 분말을 첨가한 김부각의 품질특성(18), 현미와 다시마분말의 첨가수준을 달리한 증편의 품질특성 (19) 등이 있으며, 최근 다시마로부터 유산균 발효를 통해 $\mathrm{GABA}$ 를 추출하는 발효 기술이 개발되어 이를 활용한 건강 기능성 식품 소재의 개발 및 검증이 활발하게 진행되고 있다(20,21).

최근 다시마의 기능성이 사회적으로 부각되면서 다시마 를 이용한 다양한 식품들이 새로이 개발되고 있으며, 이중 다시마를 이용하는 식초 제조 방법과 품질특성에 대한 연구 들이 비교적 활발히 이루어지고 있으나 $(11,12)$, 식초의 기 능성에 관한 연구들은 거의 없는 실정이다. 따라서 본 연구 에서는 다시마를 첨가하여 제조된 다시마 식초의 항산화 활성 및 항염증 활성에 관하여 비교 평가하였다.

\section{재료 및 방법}

\section{실험 재료}

식초의 제조에 사용한 건조다시마는 자연 건조된 장흥산 (2018)을 사용하였으며, 미생물 발효 시 당원으로 사용되는 사과농축액은 경북능금협동조합(Daegu, Korea)에서 수매 된 제품을 시중에서 구매하여 사용하였다.

\section{다시마 첨가 발효식초의 제조}

다시마 첨가 발효식초(VAST)는 Jung(22)의 제조 방법에 준하여 제조하였다. 즉, 건조다시마를 흐르는 물에 2회 수 세하고, 건조기(NEX-150, Nexus Technologies Co., Ltd.,
Seoul, Korea)에서 12시간 동안 건조한 후 분쇄기(NSG-100 2SS, Hanil, Seoul, Korea)를 활용하여 $5 \mu \mathrm{m}$ mesh을 통과한 분쇄물을 사용하였다. 다시마 첨가 식초를 제조하기위하여 분쇄된 건조다시마 $30 \%(\mathrm{w} / \mathrm{v})$, 사과농축액 $21.6 \%(\mathrm{v} / \mathrm{v})$ 및 정제수 $43.4 \%(\mathrm{v} / \mathrm{v})$ 에 효모 $5 \%(\mathrm{w} / \mathrm{v})$ 를 접종하여 $30^{\circ} \mathrm{C}$ 의 배 양기(HB-103-2H, Hanbaek Scientific Co., Bucheon, Korea) 에서 5 일간 배양하며 알코올 발효액을 제조하였고, 다시마 무 첨가 식초(VNAST)는 상기 제조 방법 중 건조다시마를 첨가하지 않고 동량을 정제수를 첨가하여 제조하였다. 초 산발효는 상기 알코올 발효액을 여과한 후 종초 $10 \%(\mathrm{v} / \mathrm{v})$ 를 접종하여 $30^{\circ} \mathrm{C}$ 에서 7 일 동안 배양하여 본 실험에서 비교할 다시마 첨가 식초 및 다시마 무첨가 식초를 제조하였으며, pH meter기(Thermo Scientific Orion Star A211, Waltham, MA, USA)로 측정한 최종 다시마 첨가 및 무첨가 식초의 산도는 각각 $4.3 \pm 0.5 \%$ 및 $4.2 \pm 0.6 \%$ 로 나타났다.

\section{$\mathrm{DPPH}$ 라디칼 소거능 평가}

1,1-Diphenyl-2-picrylhydrazyl(DPPH, Sigma-Aldrich Co., St. Louis, MO, USA) 라디칼 소거능은 Kim 등(23)의 방법을 일부 수정하여 분석하였다. 메탄올에 용해된 $0.1 \mathrm{mM}$ 의 $\mathrm{DPPH}$ 용액 $100 \mu \mathrm{L}$ 에 동량의 VNAST 및 VAST 식초 원액을 $2.5,5,10,20,100$ 배로 증류수에 희석한 용액을 첨가한 후 암실에서 30 분간 반응시킨 다음 microplate reader(Epoch, BioTek, Winooski, VT, USA)를 이용하여 $517 \mathrm{~nm}$ 에서 흡광 도를 측정하였다.

\section{ABTS 라디칼 소거능 평가}

$\mathrm{ABTS}$ 라디칼 소거능은 $\mathrm{Kim}$ 등(23)의 방법에 따라 수행 하였다. 증류수에 $7 \mathrm{mM}$ 농도로 용해된 ABTS(SigmaAldrich Co.)에 희석 배수(2.5, 5, 10, 20 및 100)별 VNAST 및 VAST 식초 원액을 $20 \mu \mathrm{L}$ 씩 96-well plate에 분주한 후 $\mathrm{ABTS}$ 용해액을 $180 \mu \mathrm{L}$ 를 가하여 암실에서 1시간 방치 한 후 microplate reader(Epoch, BioTek)를 이용하여 $762 \mathrm{~nm}$ 에 서 흡광도를 측정하였다.

\section{환원력 평가}

환원력은 Biglari 등(24)의 방법을 변형하여 측정하였다. $0.3 \mathrm{M}$ sodium acetate buffer(pH 3.6), $10 \mathrm{mM}$ TPTZ (Sigma-Aldrich Co.) 및 $20 \mathrm{mM} \mathrm{FeCl} \cdot 6 \mathrm{H}_{2} \mathrm{O}$ 를 제조하여 실 험 직전에 10:1:1의 비율로 혼합하여 ferric reducing ability of plasma(FRAP)용액을 제조하였다. FRAP 용액 $750 \mu \mathrm{L}$ 에 희석 배수 $(2.5,5,10,20)$ 별 VNAST 및 VAST 식초 희석액을 $30 \mu \mathrm{L}$ 씩 첨가한 후 $37^{\circ} \mathrm{C}$ 항온수조에서 15 분간 반응 후 microplate reader(Epoch, BioTek)를 이용하여 $593 \mathrm{~nm}$ 에서 흡광도를 측정하였다. 


\section{총 폴리페놀 함량 측정}

시료의 총 폴리페놀 함량은 Folin과 Denis(25)의 방법을 일부 수정하여 분석하였다. VNAST 및 VAST 식초 원액 $20 \mu \mathrm{L}$ 에 증류수 $400 \mu \mathrm{L}$ 를 가한 다음, 2 N Folin-Ciocalteu phenol reagent(Sigma-Aldrich Co.) $40 \mu \mathrm{L}$ 넣은 후 교반하였 다. 이 용액에 $20 \% \mathrm{Na}_{2} \mathrm{CO}_{3} 400 \mu \mathrm{L}$ 를 가한 후 $37^{\circ} \mathrm{C}$ 에서 30 분 동안 반응시킨 후 microplate reader(Epoch, BioTek)를 이용하여 $765 \mathrm{~nm}$ 에서 흡광도를 측정하였다. 총 폴리페놀 정량은 gallic acid(Sigma-Aldrich Co.)를 표준물질로 사용하 여 작성한 표준곡선으로부터 산출하였다.

\section{총 플라보노이드 함량 측정}

시료의 총 플라보노이드의 함량은 Davis(26) 방법을 일부 변형하여 분석하였다. VNAST 및 VAST 식초 원액 500 $\mu \mathrm{L}$ 에 diethylene glycol(Sima-Aldrich Co.) $5 \mathrm{~mL}$ 과 $1 \mathrm{~N} \mathrm{NaOH}$ $500 \mu \mathrm{L}$ 을 혼합하여, $37^{\circ} \mathrm{C}$ 항온 수조에서 1 시간 동안 반응시 켰다. 흡광도의 변화는 microplate reader(Epoch, BioTek)를 이용하여 $420 \mathrm{~nm}$ 에서 측정하였으며, 총 플라보노이드 함량 은 Naringin(Sigma-Aldrich Co.)을 표준물질로 사용하여 작 성한 표준곡선으로부터 산출하였다.

\section{세포배양}

마우스 기원의 대식세포주인 RAW 264.7 cell은 한국세 포주은행(KCLB, Korea cell line bank, Seoul, Korea)에서 분양받아 사용하였으며, 세포 배양을 위해 $100 \mathrm{unit} / \mathrm{mL}$ penicillin 및 $100 \mathrm{unit} / \mathrm{mL}$ streptomycin과 10\% Fetal bovine serum(FBS)를 포함하는 Roswell Park Memorial Institute (RPMI) 1640 배지(Life Technology, Carlsbad, CA, USA)를 사용하였으며, 세포는 $37^{\circ} \mathrm{C}, 5 \% \mathrm{CO}_{2}$ incubator(Thermo, Carlsbad, CA, USA)에서 배양하였다.

\section{세포생존율 평가}

RAW 264.7 cell을 96-well plate에 $3 \times 10^{4}$ cell/well의 농도 로 분주한 후 $37^{\circ} \mathrm{C}, 5 \% \mathrm{CO}_{2}$ incubator(Thermo)에서 12 시간 동안 배양하면서 세포를 완전히 부착시고, 시료를 멸균시 키기 위하여 $120^{\circ} \mathrm{C}$ 에서 10 분간 처리한 후 $0.22 \mu \mathrm{M}$ 필터로 거른 VNAST 및 VAST 식초 원액을 PBS(Phosphate Buffered Saline, WelGene, Daegu, Korea)에 희석하여 희석 배율 $(200,400,800)$ 별 시료를 처리하고 24 시간 동안 방치하 였다. Well당 $30 \mu \mathrm{L}$ 의 3-[4,5-dimethylthiazol-2-yl]-2,5diphenyltetrazolium bromide; thiazolyl blue(MTT; SigmaAldrich Co.) 용액 $(5 \mathrm{mg} / \mathrm{mL})$ 을 $30 \mu \mathrm{L}$ 첨가하여 4시간 동안 반응시켰다. MTT시약의 첨가로 형성된 포마잔(formazan) 을 녹이기 위해서 dimethyl sulfoxide(DMSO, Sima-Aldrich Co.)를 $100 \mu \mathrm{L}$ 씩 첨가하고 1 시간 후, microplate reader (Epoch, BioTek)를 이용하여 $517 \mathrm{~nm}$ 에서 흡광도를 측정하 였고, 대조구(medium only)의 흡광도 값을 기준으로 세포 생존율을 비교하였다.

\section{사이토카인 분비 억제능 평가}

48-well plate에 RAW 264.7 cell을 $6 \times 10^{4}$ cell/well로 분주 한 후 $37^{\circ} \mathrm{C}, 5 \% \mathrm{CO}_{2}$ incubator(Thermo)에서 12 시간 동안 배양하면서 세포를 완전히 부착시키고, $\mathrm{PBS}$ 에 멸균 VNAST 및 VAST 식초 원액을 PBS(WelGene)에 희석하여 희석배율 $(200,400,800)$ 별 시료를 처리하여 24 시간 동안 배양하고 배양 상층액을 분리하였다. 분리된 배양 상층액 에서 염증성 사이토카인 TNF- $a$ 의 함량을 측정하였다. 사이 토카인 함량은 ELISA kit(eBioscience Co., San Diege, CA, USA)을 사용하여 측정하였다.

\section{산화질소 분비 억제능 평가}

상기 실험에서 분리된 배양 상층액 $100 \mu \mathrm{L}$ 에 동량의 Griess(Sigma-Aldrich Co.) 시약을 처리하여 10 분 동안 반응 시킨 후 microplate reader(Epoch, BioTek)를 이용하여 517 $\mathrm{nm}$ 에서 흡광도를 측정하였다. 산화질소의 농도는 sodium nitrite $\left(\mathrm{NaNO}_{2}\right.$, Sigma-Aldrich Co.)를 사용하여 얻은 표준 곡선과 비교하여 산출하였다.

\section{통계처리}

실험에서 얻어진 결과는 Statistical Package for Social Sciences(SPSS, 10.0, IBM, Chicago, IL, USA)를 이용하여 one-way ANOVA test로 분석하였으며, 시료 간의 유의성은 Student's t-test로 ${ }^{*} \mathrm{p}<0.05,{ }^{* *} \mathrm{p}<0.01$ 수준에서 비교하였다.

\section{결과 및 고찰}

\section{다시마 첨가에 따른 식초의 라디칼 소거능 비교}

다시마 첨가 식초의 항산화 활성에 관하여 평가하기 위 하여, 다시마 첨가 식초(VAST) 및 다시마 무 첨가 식초 (VNAST)에 관하여 DPPH 및 $\mathrm{ABTS}$ 라디칼 소거능을 측정 하였다(Fig. 1). VNAST와 VAST의 희석배율(2.5, 5, 10, 20 및 100 배 희석)별 $\mathrm{DPPH}$ 라디칼 소거능에 관하여 관찰한 결과, 두 시료 모두에서 희석배율이 증가 할수록 DPPH라디 칼 소거능은 감소하였고, 2.5 배 희석액에서 가장 높은 라디 칼 소거능 수치를 나타내었다. 두 시료간 유의적인 차이는 10 배 이하의 희석액에서 나타났으며 $(10,5,2.5$ 배 $)(\mathrm{p}<0.05)$, 10 배 희석액 각각 시료의 라디칼 소거능 수치는 VNAST $5.5 \pm 1.4 \%$, VAST $16.4 \pm 0.8 \%$ 이고, 5 배 희석액에서는 VNAST $11.4 \pm 1.2 \%$ 및 VAST $24.6 \pm 1.7 \%$ 이고, 2.5 배 희석액 에서는 VNAST $21.1 \pm 1.0 \%$ 및 VAST $52.8 \pm 1.6 \%$ 로, VAST 에서 $\mathrm{DPPH}$ 라디칼 소거능이 유의적으로 증가되는 것으로 관찰되었다 $(\mathrm{p}<0.05)$. VNAST와 VAST의 희석배율 $(2.5,5$, 10,20 및 100 배 희석)별 $\mathrm{ABTS}$ 라디칼 소거능에 관하여 관찰한 결과, VNAST와 VAST 모두에서 희석배율이 증가 할수록 $\mathrm{ABTS}$ 라디칼 소거능이 감소하는 것으로 관찰되었 
고, 특히 2.5 배 희석액에서 가장 높은 라디칼 소거능 수치를 나타내었다. 두 시료간 유의적인 차이는 5 배 이하의 희석액 에서 나타났으며 $(5,2.5$ 배 $)(\mathrm{p}<0.05), 5$ 배 희석액에서는 VNAST $9.2 \pm 0.3 \%$ 및 VAST $19.1 \pm 1.5 \%$ 이고, 2.5 배 희석액 에서는 VNAST $14.6 \pm 0.9 \%$ 및 VAST $31.7 \pm 1.2 \%$ 로, VAST 에서 $\mathrm{DPPH}$ 라디칼 소거능이 유의적으로 증가되었다 $(\mathrm{p}<0.05)$.
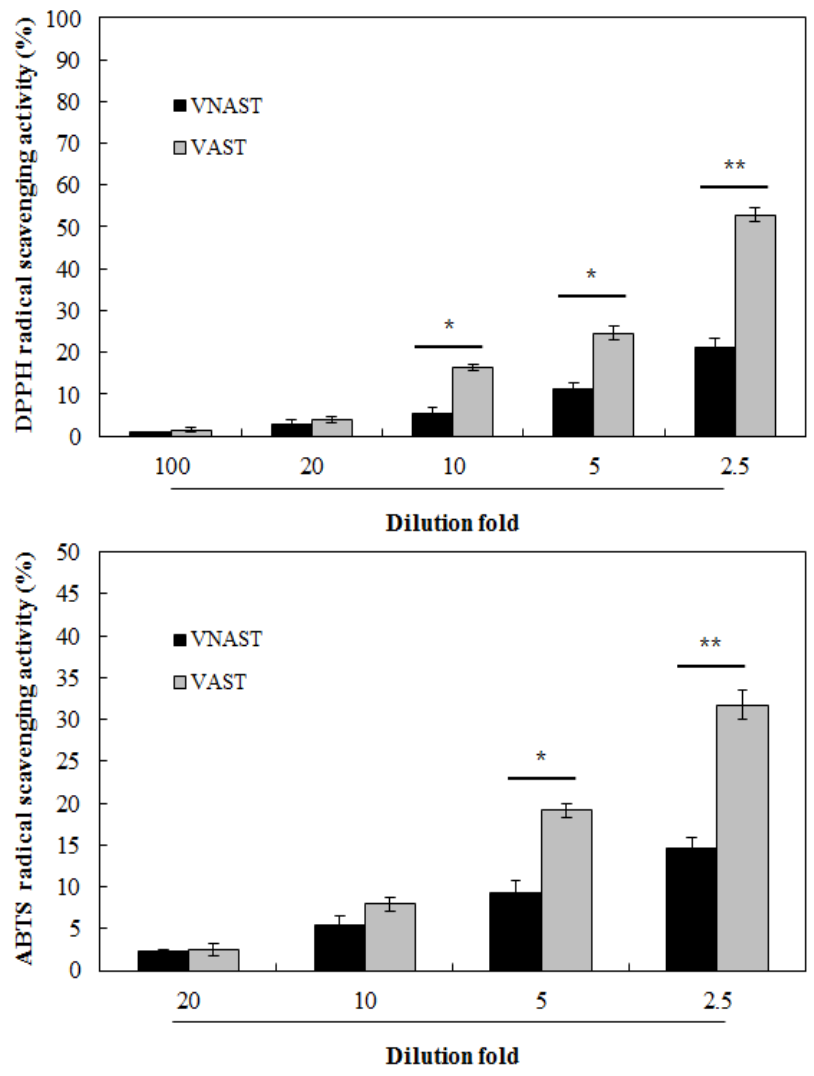

Fig. 1. DPPH and ABTS radical scavenging activities of vinegar added with sea tangle (VAST) and vinegar non-added sea tangle (VNAST).

VAST and VNAST were diluted at 2.5, 5, 10,20, 100 fold. Results were expressed the radical scavenging activities as inhibition percent. Statistical analysis was performed by unpaired Student's t-test within ${ }^{*} \mathrm{p}<0.05,{ }^{* *} \mathrm{p}<0.01$ when compared to the VNAST group.

본 연구에서 초산 발효 식초 제조에 사용된 다시마는 알긴산(alginate), 후코이단(fucoidan), 라미나란(laminaran) 등의 전자 공여능이 높은 황(sulfur)기를 갖는 다당류들을 다량으로 함유하고 있으며(27), 그 밖에 해조류에서 발견되 는 다양한 폴리페놀류와 플라보노이드 계열의 화합물을 함유하고 있어 체내 생성된 자유라디칼을 효과적으로 제거 하고 노화 및 성인병 예방에 효과가 높다는 연구들이 다양 하게 보고되고 있다(28). 본 연구에서도 다시마 첨가 식초 (VAST)에서 DPPH 및 $\mathrm{ABTS}$ 라디칼 소거능이 증가된 것은 다시마에 함유되어 있는 다양한 기능성 성분들의 영향으로 사료 된다.
다시마 첨가에 따른 식초의 환원력 비교

환원력의 측정은 페놀성 화합물에 의해 $\mathrm{Fe}^{+3}$ 이온이 $\mathrm{Fe}^{+2}$ 으로 환원되어 TPTZ와 결합하여 군청색을 가지는 복합체 를 형성하는 원리를 이용한 방법으로 환원시키는 능력이 강할수록 진한 파란색으로 발색되어 높은 흡광도를 나타낸 다(28). 환원력이 클수록 활성산소를 제거하므로 여러 질병 을 예방하는 효과가 있어 환원력이 큰 물질일수록 이용가치 가 크다.

다시마 첨가 식초의 항산화 활성에 변화에 관하여 알아 보기 위하여, 다시마 첨가 식초(VAST) 및 다시마 무 첨가 식초(VNAST)의 환원력을 측정하였다. VNAST와 VAST의 희석배율 $(2.5,5$ 및 10 배 희석)별 환원력에 관하여 관찰한 결과, 두 시료 모두에서 희석배율이 증가 할수록 환원력이 감소하였고, 2.5 배 희석액에서 가장 높은 라디칼 소거능 수치를 나타내었다(Fig. 2). 두 시료 간 유의적(p<0.05, $\mathrm{p}<0.01)$ 인 차이는 5 배 이하의 희석액에서 나타났으며 $(5$ 배 및 2.5 배), 5 배 희석액에서는 VNAST $0.22 \pm 0.02 \%$ 및 VAST $0.30 \pm 0.02 \%$ 이고, 2.5 배에서는 VNAST $0.35 \pm 0.03 \%$ 및 VAST $0.58 \pm 0.03 \%$ 로, VAST에서 환원력이 유의적 $(\mathrm{p}<0.05$, $\mathrm{p}<0.01)$ 으로 증가되었다. 본 연구 결과에 따르면, 다시마 첨가 발효 식초(VAST)에서 상기 라디칼 소거능 증가와 유사하게 환원력이 증가되는 것으로 나타났고, 환원력 값 의 증가는 특히 페놀성 화합물의 함량과 밀접한 관계에 있기 때문에, 본 연구에서도 FRAP 값 및 $\mathrm{ABTS}$ 소거능의 증가에 관한 이유에 관하여 알아보기 위하여 초산 발효 다시마 식초의 총 폴리페놀 함량과 총 플라보노이드 함량에 관하여 비교하였다.

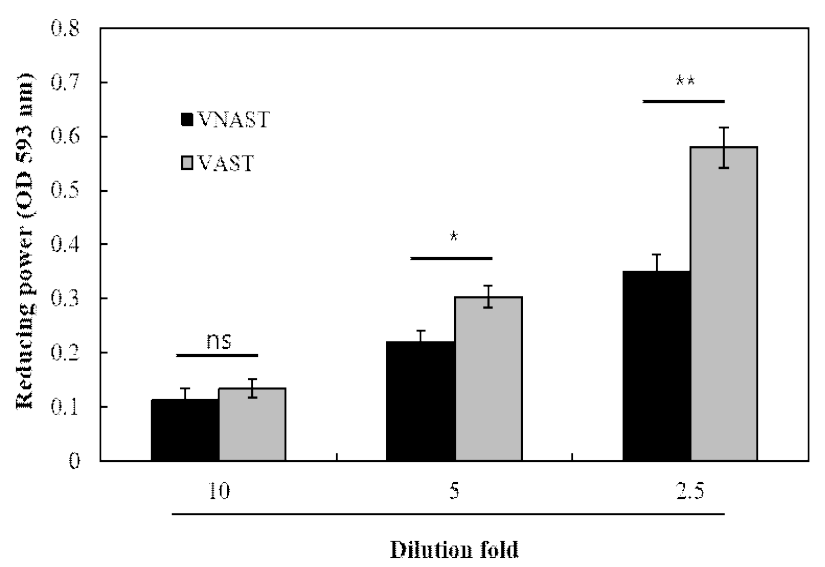

Fig. 2. Reducing power of vinegar added with sea tangle (VAST) and vinegar non-added sea tangle (VNAST).

VAST and VNAST were diluted at 2.5, 5, and 10 fold. Results were expressed the radical scavenging activities as inhibition percent. Statistical analysis was performed by unpaired Student's t-test within ${ }^{*} \mathrm{p}<0.05,{ }^{* *} \mathrm{p}<0.01$ when compared to the VNAST group. n.s means non-significant. 
다시마 첨가에 따른 식초의 총 폴리페놀 및 총 플라보노 이드 함량 비교

폴리페놀성 화합물과 플라보노이드 화합물은 주로 자연 식물계에 널리 분포되고 있다. 그들은 화학적 구조가 다양 하여 작용기의 종류에 따라서 기능에 영향을 주는 것으로 알려져 있으며 $(29,30)$, 식품에 색과 향을 부여하며 항산화 능력, 심혈관 질환과 암의 예방적 기능을 하는 것으로 알려 져 있다 $(31,32)$.

다시마 첨가 식초의 항산화 활성 증가에 대한 이유에 관하여 알아보기 위하여, 다시마 첨가 식초(VAST) 및 다시 마 무 첨가 식초(VNAST)에 관하여 총 폴리페놀 함량 및 총 플라보노이드 함량에 관하여 측정하였다(Table 1).

VNAST와 VAST의 환원력에 관하여 관찰한 결과, 총 폴리페놀의 함량은 VNAST $9.12 \pm 0.15 \mathrm{mg} / \mathrm{mL}$ 및 VAST $15.7 \pm 0.75 \mathrm{mg} / \mathrm{mL}$ 로 다시마 첨가 식초에서 유의적으로 높 게 관찰되었으며 $(\mathrm{p}<0.05)$, 총 플라보노이드 함량은 VNAST $1.35 \pm 0.15 \mathrm{mg} / \mathrm{mL}$ 및 VAST $3.58 \pm 0.23 \mathrm{mg} / \mathrm{mL}$ 로 다시마 첨 가 식초에서 유의적으로 높게 나타났다 $(\mathrm{p}<0.05)$.

폴리페놀 및 플라보노이드는 강력한 항산화 활성 $(30,32)$ 을 가지고 있어, 라디칼을 효과적으로 제거하고 이온의 환 원력에 영향을 주고, 강력한 염증 억제 반응을 보이며, 암세 포의 억제에도 깊이 관여하고 있다고 보고되어진다. 따라 서 상기 실험에서 다시마 발효 식초에서 $\mathrm{DPPH}, \mathrm{ABTS}$ 라디 칼 소거능 증가 및 환원력 증가는 다시마 첨가에 따른 식초 의 총 폴리페놀 및 총 플라보노이드의 함량 증가의 원인으 로 사료된다.

Table 1. Total polyphenolic compounds and total flavonoid contents of VNAST and VAST

\begin{tabular}{ccc}
\hline Sample $^{1)}$ & $\begin{array}{c}\text { Total polyphenol content } \\
\text { (gallic acid, } \mathrm{mg} / \mathrm{mL} \text { ) }\end{array}$ & $\begin{array}{c}\text { Total flavonoid content } \\
\text { (naringin, } \mathrm{mg} / \mathrm{mL} \text { ) }\end{array}$ \\
\hline VNAST & $9.12 \pm 0.51^{2)}$ & $1.35 \pm 0.15$ \\
VAST & $15.71 \pm 0.75^{* 3)}$ & $3.58 \pm 0.23^{*}$ \\
\hline
\end{tabular}

${ }^{1)}$ VNAST, vinegar non-added sea tangle; VAST, vinegar added sea tangle.

${ }^{2)}$ Values are expressed as mean \pm SD. Statistical analysis was performed by unpaired Student's t-test.

3) ${ }^{*}<0.05,{ }^{* *} \mathrm{p}<0.01$ when compared to the VNAST group.

\section{다시마 첨가에 따른 식초의 세포 생존율 측정}

다시마 첨가 식초의 항염증 활성에 관하여 알아보기 위 하여, 대식세포에 대한 다시마 첨가 식초 및 무첨가 식초를 처리하여 세포 생존율에 관하여 측정하였다(Fig. 3). 마우스 유래의 대식세포주인 RAW 264.7 세포에 희석배율(200, 400 및 800배) VNAST와 VAST를 처리한 결과, 모든 농도에 서 세포독성은 관찰되지 않았다. 따라서 VNAST와 VAST 의 처리는 면역세포인 대식세포의 세포독성에 영향을 미치 지 않는 것으로 사료되며, 추후 VNAST와 VAST의 처리가 LPS로 유도된 염증 모델에서 사이토카인 및 산화질소의
억제능에 어떠한 영향을 미치는지 알아보기 위하여 VAST 와 VAST의 처리 농도를 200 배 이하로 설정하였다.

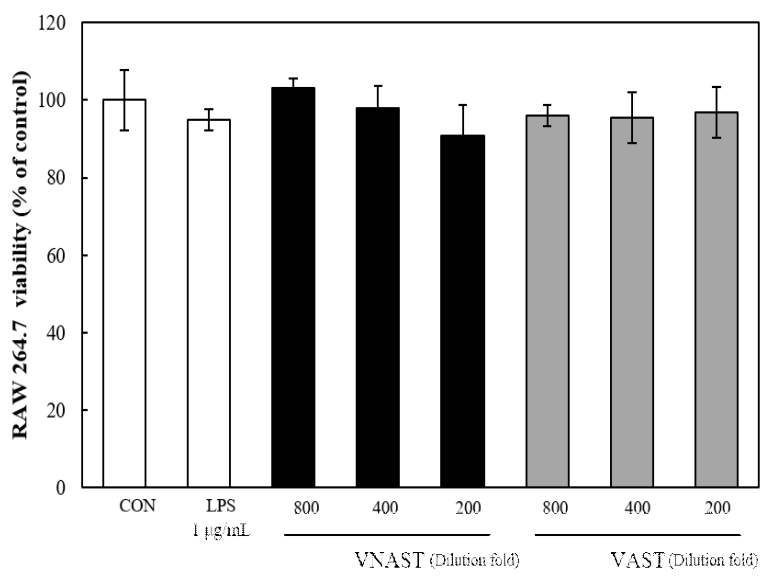

Fig. 3. Cell viability of vinegar added with sea tangle (VAST) and vinegar non-added sea tangle (VNAST).

VAST and VNAST were diluted at the 200, 400, 800 fold and treated on RAW 264.7 cell. Cell viability was measured by MTT. The data represent the mean \pm SD $(n=3)$.

다시마 첨가에 따른 식초의 산화질소 분비 억제능 비교

비특이적 항원의 침입에 의해 활성화된 대식세포는 항원 을 포식하고, 항원에 대한 정보를 후천면역반응에서 주된 역할을 하는 $\mathrm{T}$ 세포에 제시해 세포매개성 반응의 활성을 유도한다. 과도한 면역반응(염증) 반응시 과활성화된 대식 세포가 분비하는 산화질소는 L-arginine으로부터 iNOS에 의해 과량 생성되며, 소량의 산화질소는 생체 내 감염을 일으키는 항원을 효과적으로 제어할 수 있지만 과량의 산화 질소는 또다른 염증 반응을 매개시키는 수단으로 사용되 어, 초기 염증 반응 시 산화질소의 분비능은 염증 조절의 중요한 지표로 사용된다(33).

다시마 첨가 식초의 항염증 활성에 관하여 알아보기 위 하여, 다시마 첨가 식초(VAST) 및 다시마 무첨가 식초 (VNAST)에 관하여 LPS처리 염증유도 대식세포 모델에서 LPS에 의해 유도되는 NO 분비 억제능에 관하여 측정하였 다(Fig. 4). VNAST와 VAST를 희석배율 $(200,400,800$, 1,600 배 희석)별 $\mathrm{LPS}(1 \mu \mathrm{g} / \mathrm{mL})$ 와 동시 처리한 결과, 두 시료 모두에서 희석배율이 감소할수록 NO 분비가 억제되는 것 으로 나타났고, 200 배 희석액 처리구에서 가장 낮은 NO분 비능이 관찰되었다. 두 시료간 유의적인 차이는 800 배 이하 희석액에서 나타났으며(800, 400 및 200배)(p<0.05), 800배 희석액에서는 VNAST $19.0 \pm 1.0 \mu \mathrm{M}$ 및 VAST $15.9 \pm 0.8 \mu \mathrm{M}$ 이고, 400배에서는 VNAST $17.6 \pm 1.3 \mu \mathrm{M}$ 및 VAST 14.0 \pm 0.6 $\mu \mathrm{M}$ 로 관찰되었으며, 200배에서는 VNAST $16.0 \pm 0.8 \mu \mathrm{M}$ 및 VAST $10.3 \pm 1.1 \mu \mathrm{M}$ 로, VAST 처리구에서 염증 반응 시 분비 되는 $\mathrm{NO}$ 의 분비가 유의적으로 감소되었다 $(\mathrm{p}<0.05)$. 


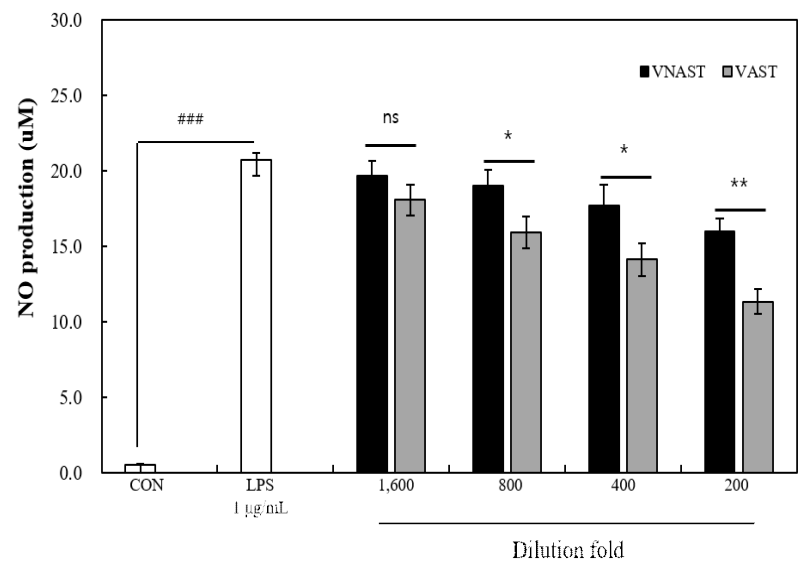

Fig. 4. Inhibition of nitric oxide (NO) production on vinegar added with sea tangle (VAST) and vinegar non-added sea tangle (VNAST) in lipopolysaccharide (LPS) treated inflammation induced RAW 264.7 cell.

VAST and VNAST were diluted at the 200, 400, 800, 1,600 fold and treated on RAW 264.7 cell. After $24 \mathrm{~h}$, NO production in culture supernatant was estimated by Griess reagent assay. The data represent the mean $\pm \mathrm{SD}(\mathrm{n}=3)$. Statistical analysis was performed by unpaired Student's t-test within $\mathrm{p}^{*}<0.05, \stackrel{*}{\mathrm{*}}<0.01$ when compared to the VNAST group.

다시마 첨가에 따른 식초의 염증성 사이토카인 억제능 비교 염증 반응 시 염증성물질에 의해 활성화된 큰포식세포는 산화질소뿐만 아니라 면역세포 간 상호작용을 매개하여 면역반응을 조절하는 역할을 수행하는 염증성 사이토카인 TNF-a, IL-6 및 IL-1 $\beta$ 등을 분비한다(7). 이 중 TNF-a(종양 괴사인자)는 염증 물질인 LPS가 대식세포의 세포 표면 toll-like receptor 4(TLR-4)에 결합하여 유도되는 대표적인 pro-inflammatory 사이토카인으로, 면역 반응을 일으키고

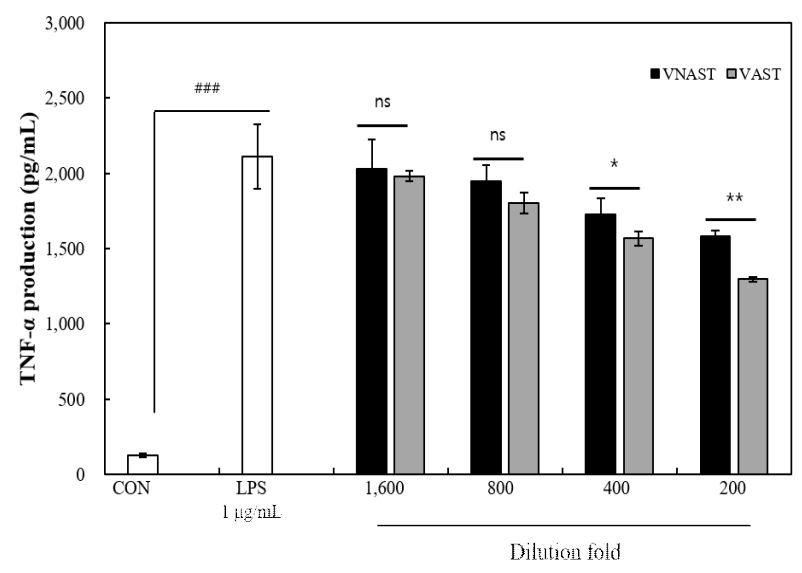

Fig. 5. Inhibition of cytokine (TNF-a) production on vinegar added with sea tangle (VAST) and vinegar non-added sea tangle (VNAST) in lipopolysaccharide (LPS) treated inflammation induced RAW 264.7 cell.

VAST and VNAST were diluted at the 200, 400, 800, 1,600 fold and treated on RAW 264.7 cell. After $24 \mathrm{~h}$, TNF-a production in culture supernatant was estimated by ELISA kit. The data represent the mean $\pm \mathrm{SD}(\mathrm{n}=3)$. Statistical analysis was performed by unpaired Student's t-test within ${ }^{*} \mathrm{p}<0.05,{ }^{* *} \mathrm{p}<0.01$ when compared to the VNAST group.
과도하게 생성되면 발열, 조직을 손상 유발, 염증반응을 촉진하게 된다(34).

본 연구에서 항염효과의 바이오마커로써 염증반응 시 증가하는 사이토카인 TNF-a의 분비 억제에 관하여 관찰하 였다(Fig. 5). VNAST와 VAST의 희석배율(200, 400, 800, 1,600 배 희석)별 $\mathrm{LPS}(1 \mu \mathrm{g} / \mathrm{mL})$ 와 동시 처리한 결과, LPS 단독 처리구 $(2,019.5 \pm 212.5 \mathrm{pg} / \mathrm{mL})$ 에 비해 두 시료 처리구 모두에서 희석배율이 감소할수록 TNF-a 분비가 억제되는 것으로 나타났고, 200 배 희석액에서 TNF-a 분비 억제가 가장 높게 나타났다. 두 시료간 유의적인 차이는 400배 이하 의 희석액 처리구에서 나타났으며(400 및 200 배 $)(\mathrm{p}<0.05)$, 400 배 희석액 처리구에서는 VNAST $1,726.0 \pm 111.5 \mathrm{pg} / \mathrm{mL}$ 및 VAST $1,568.5 \pm 46.5 \mathrm{pg} / \mathrm{mL}$ 으로 관찰되었으며, 200 배에 서는 VNAST $1,579.5 \pm 42.5 \%$ 및 VAST $1,296.0 \pm 17.0$ 으로, $\mathrm{VAST}$ 처리구에서 TNF-a 분비능이 유의적으로 감소되었 다 $(\mathrm{p}<0.05)$.

\section{요 약}

본 연구는 다시마를 첨가하여 제조한 다시마 식초의 항 산화 활성 및 항염 활성 등의 생리활성 변화를 비교하여 평가하였다. 라디칼 소거능 및 환원력 평가를 통하여 다시 마 첨가 식초(VAST)의 항산화 활성이 무첨가구와 비교하 였을 때 유의적으로 증가하는 것으로 나타났으며, 총 폴리 페놀 함량 및 총 플라보노이드 함량 또한 다시마 첨가 식초 에서 유의적인 증가를 나타냈다. 따라서, 다시마 첨가 식초 의 항산화 활성 증가는 총 폴리페놀 및 총 플라보노이드의 함량과 증가에 의한 것으로 사료되며, LPS 처리 염증 유도 대식세포 모델에서, 다시마 첨가 식초(VAST) 처리구에서 염증성 인자인 NO 및 TNF-a의 분비가 유의적으로 억제되 는 것으로 나타났다. 따라서 다시마 발효 식초는 다시마 무첨가 식초와 비교하여 볼 때 항산화 및 항염증 활성이 높은 것으로 판단되고, 식초 뿐만 아니라 다시마의 이러한 기능성을 활용한 다양한 식품의 개발이 가능하리라 사료된 다.

\section{감사의 글}

본 연구에 도움을 주신 한국프라임제약(주)에 감사드립 니다.

\section{References}

1. Jeong YJ, Seo KI, Kim KS (1996) Physicochemical 
properties of marketing and intensive persimmon vinegars. J East Asian Soc Dietary Life, 6, 355-363

2. Park MY, Kim KH, Jeong KS, Kim HA (2007) Effect of supplementation of dietary sea tangle on the renal oxidative stress in diabetic rats. Korean J Food Culture, 22, $140-148$

3. Joo KH, Cho MH, Park KJ, Jeong SW, Lim JH (2009) Effects of fermentation method and brown rice content on quality characteristics of brown rice vinegar. Korean J Food Preserv, 16, 33-39

4. Jo DJ, Park EJ, Yeo SH, Jeong YJ, Kwon JH (2013) Physicochemical and antioxidant properties of commercial vinegars with high acidity. J Korean Soc Food Sci Nutr, 42, 1204-1210

5. Hong KP (2015) Inhibitory effects of fatty acids, polyphenols and organic acids on the glucoamylase activity. MS Thesis. Korea University, Korea. p 8

6. Xu Q, Tao W, Ao Z (2007) Antioxidant activity of vinegar melanoidins. Food Chem, 102, 841-849

7. Budak NH, Aykin E, Seydim AC, Greene AK, Guzel-Seydim ZB (2014) Functional properties of vinegar. J Food Sci, 79, 757-764

8. Yi MR, Kang CH, Bu HJ (2017) Acetic acid fermentation properties and antioxidant activity of lemongrass vinegar. Korean J Food Preserv, 24, 680-687

9. MFDS Korea Food and Drug Administration. https://www.foodsafetykorea.go.kr/foodcode/03_02.jsp?i $\mathrm{dx}=33$ (accessed Feb, 2018)

10. Jeong EJ, Park HJ, Cha YJ (2016) Fermented production of onion vinegar and its biological activities. Korean $\mathrm{J}$ Food Nutr, 29, 962-970

11. Hwang JY, Cho HY, Pyo YH (2016) Effect of unpolished rice vinegar containing monascus-fermented soybean on inhibitory activities of tyrosinase and elastase. J Korean Soc Food Sci Nutr, 45, 149-154

12. Cho KM, Hwang CE, Joo OS (2017) Change of physicochemical properties, phytochemical contents and biological activities during the vinegar fermentation of Elaeagnus multiflora fruit. Korean J Food Preserv, 24, 125-133

13. Baek JM (2007) Present state and prospect in seaweed farming industry. In: J East Asian Soc Dietary Life $32^{\text {th }}$ Annual Meeting of the Seaweed and Food. April 28, Seoul, Korea, p 15-22

14. Kim JS and Kwak EJ (2011) Quality characteristics of gruel with added yam. Korean J Food Culture, 26, 184-189
15. Cho YJ and Bang MA (2004) Effects of dietary sea tangle on blood glucose, lipid and glutathione enzymes in streptozotocin-induced diabetic rats. Korean J Food Culture, 19, 419-428

16. Kang YM, Lee BJ, Kim JS (2010) Alcohol metabolizing activity of fermented sea tangle juice. Korean J Fish Aquat Sci, 43, 1-5

17. Kwon YR and Youn KS (2012) Quality and antioxidant characteristics of granule tea prepared with sea tangle (Laminaria japonica) and sea mustard (Undaria pinnatifida) powder as affected by extraction method. Korean J Food Preserv, 19, 525-531

18. Choi HM, Sim CH, Shin TS, Bing DJ, Chun SS (2011) Quality characteristics of Kimbugak with sea tangle powder. Korean J Food Nutr, 24, 434-441

19. Lee MW, Lee IS (2016) Quality characteristics of jeungpyun prepared with brown rice and sea tangle powder. Korean J Food Cook Sci, 32, 178-187

20. Lee BJ (2013) Development of functional food using fermented marine organism. Food Industry and Nutrition, $18,8-12$

21. Ryu JK, Jo YH, Chang SJ, Lee BJ (2016) Memoryimproving effects of fermented sea tangle Saccharina japonica in normal mice. Korean J Fish Aquat Sci 49, 131-136

22. Jung YJ (2009) Quality characteristics of alcoholic beverage, vinegar, and rice cake using Plurouts osteratus, Flammulina velutipes and Grifola frondosa. MS Thesis. Seoul National University, Korea, p 12

23. Kim EJ, Choi JY, Yu M, Kim MY, Lee S, Lee BH (2012) Total polyphenols, total flavonoid contents, and antioxidant activity of Korean natural and medicinal plants. Korean J Food Sci Technol, 44, 337-342

24. Biglari F, AIKarkhi AMF, Easa AM (2008) Antioxidant activity and phenolic content of various date palm (Phoenix dactylifera) fruits from Iran. Food Chem, 107, 1636-1641

25. Folin O, Dennis W (1912) On phosphotungsticphosphomolybdic compounds as color reagents. J Biol Chem, 12, 239-243

26. Davis WB (1947) Determination of flavanones in citrus fruits. Anal Chem, 19, 476-478

27. Jin DQ, Li G, Kim JS, Young CS, Kim JA, Hun K (2004) Preventive effects of Laminaria japonica aqueous extraction the oxidative stress and xanthine oxidase activity in streptozotocin-induced diabetic rat liver. Biol Pharm Bull, 27, 1037-1040 
28. Park MY, Kim KH, Jeong KS, Kim HA (2007) Effect of supplementation of dietary sea tangle on the renal oxidative stress in diabetic rats. Korean J Food Culture, 22, $140-148$

29. Cook NC, Samman S (1996) Flavonoids-chemistry, metabolism, cardioprotective effects, and dietary sources. J Nutr Biochem, 7, 66-76

30. Yordi EG, Perez EM, Matos MJ, Villares EU (2012) Antioxidant and pro-oxidant effects of polyphenolic compounds and structure-activity relationship evidence. In: Nutrition, Well-Being and Health. Bouayed J, Bohn $\mathrm{T}$ (Editor) InTech Publisher, Shanghai, China, p 23-48

31. Ghasemzadeh A, Ghasemzadeh N (2011) Flavonoids and phenolic acids: role and biochemical activity in plants and human. J Med Plants Res, 5, 6697-6703
32. Scalbert A, Johnson IT, Saltmarsh M (2005) Polyphenols: antioxidants and beyond. Am J Clin Nutr, 81, 215S-217S

33. Lee J, Yeon Y, Seong S, Bae W. 2016. The long-term growth characteristics of vegetation base materials include spent coffee ground. J Korean Geo-Environ Soc, $17,45-53$

34. Han MH, Lee MH, Hong SH, Choi YH, Moon JS, Song MK, Kim MJ, Shin SJ, Hwang J (2014) Comparison of anti-inflammatory activities among ethanol extracts of Sophora flavescens, Glycyrrhiza uralensis and Dictamnus dasycarpus and their mixtures in RAW 264.7 murine macrophages. J Life Sci, 24, 329-335 